\title{
The Effects of Price Perception, Product Knowledge, Company Image, and Perceived Value on Purchase Intentions for Automotive Products
}

\author{
Made Theoresta Taruna Jaya Ayub, Ni Made Wulandari Kusumadewi
}

\section{ABSTRACT}

The purpose of this study is to explain the effect of price perception, product knowledge, company image, and perceived value on purchase intention. The method used is purposive sampling with a sample of 120 people. The method of data collection is through the distribution of instruments. The data analysis technique used is regression analysis. The results of this study indicate that price perception has a significant positive effect on purchase intention. This shows that the higher the price perception, the higher the intention to buy the product. Product knowledge has a significant positive effect on purchase intention. This shows that the higher the product knowledge, the higher the intention to buy the product. Company image has a significant positive effect on purchase intention. This shows that the better the company's image, the higher the purchase intention. Perceived value has a significant positive effect on purchase intention. This shows that the higher the value of a product, the higher the purchase intention.

Keywords: Company Image, Perceived Value, Price Perception, Product Knowledge, Purchase Intention.

\section{INTRODUCTION}

In the modern era, vehicles play a very important role in helping human mobility in carrying out activities. The large number of four-wheeled vehicles in Indonesia is an opportunity as well as a challenge for every actor in the automotive sector to be able to meet the needs of the community both in terms of vehicle maintenance, availability of spare parts and aftermarket parts.

Purchase intentions arise after an alternative evaluation process, in the evaluation process a person will make a series of choices regarding the product to be purchased on the basis of brand or interest [1]. Purchase intentions can also arise if a consumer feels very interested in various information about products obtained through advertising, the experiences of people who have used them, and the urgent need for a product [2]. Companies must be able to carry out activities that aim to trigger consumer interest in buying a product and are also required to be able to recognize and know what the needs and desires of consumers are. The purchase intention of a product is the relationship between the amount of product demanded and all the factors that affect demand [3].

The better the perception of the price, the stronger the purchase intention for the product. Price is one element of the marketing mix that requires careful consideration [3]. Price is not just the exchange value of goods or services; consumers always expect a reciprocal match between the benefits of the product they receive. Companies must be aware of the consumer's desire to obtain a fair price, where sold [5]. company staff [3].
Submitted : June 24, 2021

Published : September 08, 2021

ISSN: 2507-1076

DOI: $10.24018 /$ ejbmr.2021.6.5.955

Made Theoresta Taruna Jaya Ayub Faculty of Economy and Business, Udayana University, Bali, Indonesia. (e-mail: theoresta@ ${ }^{@}$ ahoo.com) Ni Made Wulandari Kusumadewi Faculty of Economy and Business, Udayana University, Bali, Indonesia.

the costs incurred are proportional to the benefits obtained. However, other found that the price perception variable had a negative and insignificant effect on purchase intentions for clothing products [4].

Apart from the price side, a person's purchase intention is also influenced by product variables, one of which is consumer knowledge for a product (product knowledge). Product knowledge is a collection of various kinds of information about products. Consumers will dig up as much information as possible about the automotive products being

Company image affects a person's purchase intention. Corporate image is a general impression of the company that is embedded in people's minds, it is something comprehensive and a reflection of the subject's behavioral abilities [6]. Image of the company directly and clearly affects the perception of consumer cognition for the purchase intention of goods. It also shows that in the marketing environment, the social image of the company's image has the greatest effect on the perceived quality of consumers. The company's image is formed related to various physical attributes and company behavior, such as business name, architecture, various products/services, traditions, ideology and the impression of the quality of communication by each person when interacting with

A person's purchase intention is also influenced by the value of a product where the value of a product that is considered high by consumers makes them intend to make a purchase. Perceived value is the overall consumer 
assessment of the usefulness of a product for what is received and provided by the product [7]. Perceived value is an exchange that is the subject of marketing with value as an appropriate measure of any exchange, whether appropriate or not [1], based on this opinion, it can be explained that perceived value is a consumer assessment carried out by comparing the benefits the profit that can be received at the expense of a product. A bad perception of value can result in a loss of consumer purchase intention, otherwise if consumers feel that the value of the product is higher, then they are more likely to intend to buy the product [8].

\section{LITERATURE REVIEW}

"Consumers use their perception of the relative price as a way to feel the value of the product so that consumers can determine their intention to buy the product [9]. The perception of price has a partially significant positive effect on the purchase intention of online fashion products, Perception on capacity control and capability develops according to consumer age [10]."

\section{H1: "Price perception has a positive and significant effect on purchase intention"}

"Research by Rohmatun show product knowledge has a significant effect on the purchase intention of halal cosmetic products partially or simultaneously [11]. Product knowledge has an effect on purchase intention, because the more product knowledge provided by the company makes consumers have a lot of knowledge about the product, it can encourage consumers to generate purchase intentions for the product [12]. Thus, consumers tend to be aware of the value of a product so that their purchase intention also increases. Brand image and product knowledge have a positive and significant effect on purchase intention of counterfeit bag products [13]."

\section{H2: Product knowledge has a positive and significant effect on purchase intention}

"There is a positive and significant relationship between company image and purchase intention of multi-service services [3]. A significant positive direct relationship between company image and purchase intention. The better the company's image, the buying intention of mutual fund investors can increase. Research on The antecedents of purchase decision for hijab fashion products, found that the independent variable of corporate image affects the dependent variable of buying intention of fashion products [14]. Corporate image has a positive and significant influence on purchase intention of bottled drinking water products [15]."

\section{H3: "Company image has a positive and significant effect on purchase intention"}

"Perceived value had a positive and significant effect on the purchase intention. This means that the perceived value perceived by consumers can increase the purchase intention of the product, so that the higher the perceived value perceived by consumers, the higher intention to buy the product [16]. A significant relationship between Perceived Value and Purchase Intention, this can happen because the value of a product that is considered high by consumers makes them intend to make a purchase, so that products that have high value in the eyes of consumers can make sales of these products increase [17]."

\section{H4: "Perceived value has a positive and significant effect on purchase intention"}

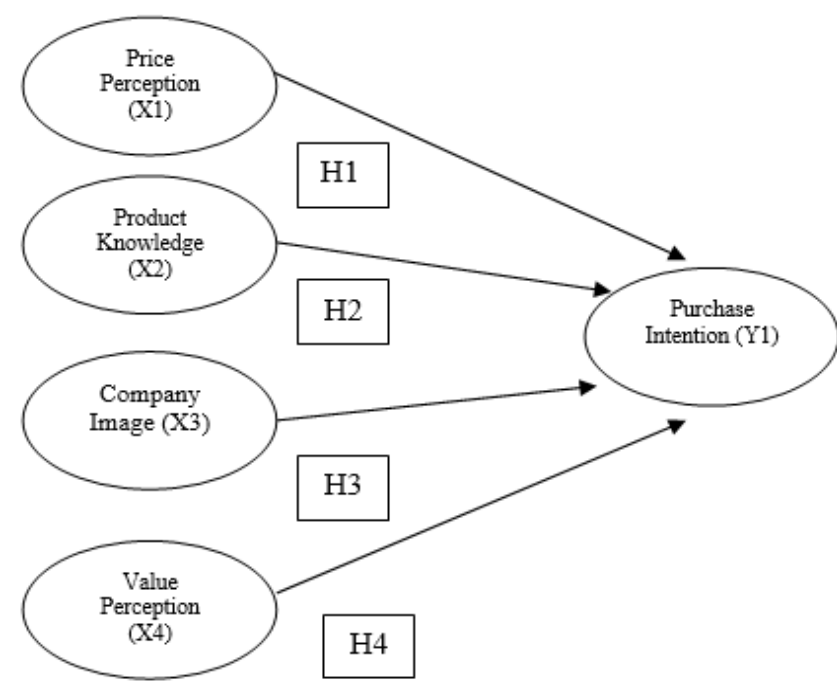

Fig. 1. Conceptual Framework.

\section{Methodology}

This research is classified as associative research. In this study, the method of determining the sample used is purposive sampling. The sample size was set at 120 people. The method used to collect data is to conduct a survey by distributing offline (direct) and online (google forms) questionnaires to respondents who meet the criteria. Questionnaires were distributed in Denpasar. Each statement that shows indicators about the five research variables is measured using a 5 (five) point Likert Scale. In this study, inferential statistical methods were used through regression analysis techniques.

\section{RESUlTS}

The analytical technique used in this study is multiple linear regression analysis to analyze the effect of the independent variables (perceived price, product knowledge, company image, and perceived value) on the dependent variable, namely purchase intention. Based on the results of the regression test using SPSS, the following results were obtained.

"Based on the results of SPSS calculations, it was found that the calculated $\mathrm{F}$ value was 51.984 which was greater than the $\mathrm{F}$ table value $(\mathrm{F}$ table $=2.45)$ and the sig test results. $\mathrm{F}$ of 0.000 which is smaller than the significant value of $0.05(0.000<0.05)$. These results indicate that price perception, product knowledge, company image, and value perception simultaneously influence the purchase 
intention of automotive products. The value of $\mathrm{R}$ square is 0.644 , which means that the influence of price perception, product knowledge, company image, and perceived value affect the purchase intention of automotive products by 64.4 percent while the remaining 35.6 percent is influenced by other factors outside the model."

TABLE I: MulTIPLE LINEAR REGRESSION TEST RESULTS

\begin{tabular}{|c|c|c|c|c|c|c|}
\hline & \multirow{2}{*}{ Model } & \multicolumn{2}{|c|}{$\begin{array}{l}\text { Unstandardized } \\
\text { Coefficients }\end{array}$} & \multirow{2}{*}{$\begin{array}{c}\begin{array}{c}\text { Standardized } \\
\text { Coefficients }\end{array} \\
\text { Beta }\end{array}$} & \multirow{2}{*}{$\mathrm{t}$} & \multirow{2}{*}{ Sig. } \\
\hline & & B & $\begin{array}{l}\text { Std. } \\
\text { Error }\end{array}$ & & & \\
\hline \multirow{8}{*}{1} & (Constant) & .056 & .299 & & .186 & .852 \\
\hline & Price Perception & .253 & .127 & .257 & 1.997 & .048 \\
\hline & Product knowledge & .183 & .085 & .174 & 2.153 & .033 \\
\hline & Company Image & .279 & .136 & .239 & 2.044 & .043 \\
\hline & Value Perception & .241 & .107 & .219 & 2.253 & .026 \\
\hline & F : 51.984 & & & & & \\
\hline & F-Sig. : .000 & & & & & \\
\hline & R Square : .644 & & & & & \\
\hline
\end{tabular}

\section{A. The Effect of Price Perception on Purchase Intention}

"The effect of price perception (X1) on purchase intention (Y1) is 0.257 with a sig.t value comparison of 0.048 less than the significant value used $(0.048<0.05)$. This shows that price perception has a positive and significant effect on purchase intention by 25.7 percent. This means that the higher the price perception, the higher the intention to buy the product. Price perception has a strong influence on purchase intention [18]. The better the consumer's perception of the price of a product, the better the consumer's purchase intention for the product [19]."

\section{B. The Effect of Product Knowledge on Purchase Intention}

"The effect of product knowledge (X2) on purchase intention (Y1) is 0.174 with a sig.t value comparison of 0.033 which is less than the significant value used $(0.033$ $<0.05)$. This figure shows that product knowledge has a positive and significant effect on purchase intention by 17.4 percent. This means that the higher the product knowledge, the higher the intention to buy the product. Product knowledge that consumers have will have an impact on the emergence of purchase intentions. Consumers with high product knowledge judge products based on their quality because they believe in the knowledge they have. Therefore, consumers are usually aware of the value of a product so that their purchase intention increases [20]."

\section{The Effect of Company Image on Purchase Intention}

"The effect of corporate image (X3) on purchase intention (Y1) is 0.239 with a sig.t value comparison of 0.043 less than the significant value used $(0.043<0.05)$. This figure shows that the company's image has a positive and significant effect on purchase intention by 23.9 percent. This means that the better the company's image, the higher the purchase intention. Buying interest is consumer behavior that appears in response to objects that show the customer's desire to make a purchase. To increase buying interest, companies need to improve a positive corporate image. Corporate image can be realized by providing the best service to consumers."

\section{The Effect of Perceived Value on Purchase Intention}

"The effect of perceived value (X4) on purchase intention (Y1) is 0.219 with a sig.t value comparison of 0.026 less than the significant value used $(0.026<0.05)$. This figure shows that perceived value has a positive and significant effect on purchase intention by 21.9 percent. This means that the higher the value of a product in the minds of consumers, it can increase the purchase intention of the product. A person's purchase intention is also influenced by the value of a product where the value of a product that is considered high by consumers makes them intend to make a purchase. Poor perception of value can result in a loss of consumer purchase intention. If consumers feel that the value of the product is higher than the sacrifices incurred for the product, then consumers are more likely to intend to buy the product."

\section{E. Research Limitations}

"This research has been proposed and carried out according to scientific procedures. However, there are still limitations in this study, including: The number of respondents is only 120 people and this study cannot represent an area and There are variables such as word of mouth and service quality that can affect purchase intentions outside the model described in this study."

\section{CONCLUSION}

Based on the results of data analysis and discussion of the influence of each variable, it can be concluded that price perception has a positive and significant effect on purchase intention. This means that the higher the price perception, the higher the intention to buy the product. Product knowledge has a positive and significant effect on purchase intention. This means that the higher the product knowledge, the higher the intention to buy the product. Company image has a positive and significant effect on purchase intention. This means that the better the company's image, the higher the purchase intention. Perceived value has a positive and significant effect on purchase intention. This means that the higher the value of a product, the higher the purchase intention

Companies that sell automotive products need to provide products with more affordable prices because these indicators get the lowest ratings based on respondents' answers to the price perception variable. This needs to be done in order to increase product purchase intentions based on price perceptions. The company also requires its employees to have broad product knowledge that is useful in explaining to consumers about the types, benefits and quality of the products sold because the higher the product knowledge that consumers have, the higher the purchase intention of the product. Companies need to increase the value of the products offered to become consumers' choices compared to other stores because these indicators get the lowest ratings based on respondents' answers to the perceived value variable. This needs to be done because the higher the value of a product in the minds of consumers, it can increase the purchase intention of the product [1]. 


\section{FUTURE RESEARCH}

it is advisable to reconsider various factors such as a larger number of respondents and using variables other than price perception, product knowledge, company image, and perceived value such as word of mouth, service quality and various other variables.

\section{REFERENCES}

[1] P. Kotler and K. L. Keller, Marketing Management, 15th ed. Pearson Education, 2016

[2] A. S. Rini, I. P. G. Sukaatmadja, and I. G. A. K. Giantari, "Pengaruh Pengetahuan Lingkungan Dan Kepedulian Lingkungan Terhadap Sikap Dan Niat Beli Produk Hijau 'The Body Shop' Di Kota Denpasar," E-Jurnal Manaj. Unud, vol. 6, no. 1, pp. 137-166, 2017.

[3] I. K. Suarjana and N. W. S. Suprapti, "Pengaruh Persepsi Harga, Pengetahuan Produk, dan Citra Perusahaan Terhadap Niat Beli Layanan Multi Servis Merek Indihome," E-Jurnal Manaj. Unud, vol. 7, no. 4, pp. 1920-1949, 2018.

[4] M. S. Yonathan and I. Sukirno, "Pengaruh Persepsi Nilai, Persepsi Kualitas, Persepsi Harga dan Citra Merek Terhadap Niat Beli Produk Pakaian Nevada (Studi Pada Mahasiswa di Fakultas Ekonomi Universitas Atma Jaya Yogyakarta),' E-Journal Univ. Atma Jaya Yogyakarta, vol. 1, no. 1, pp. 1-14, 2015.

[5] V. Sangtani and F. Murshed, "Product knowledge and salesperson performance: rethinking the role of optimism," Mark. Intell. Plan., vol. 35, no. 6, pp. 724-739, 2017, doi: https://doi.org/10.1108/MIP11-2016-0199.

[6] E. A. d. . Watanabe, C. V. Torres, and S. Alfinito, "The impact of culture, evaluation of store image and satisfaction on purchase intention at supermarkets," Rev. Gestão, vol. 26, no. 3, pp. 256-273, 2019, doi: https://doi.org/10.1108/REGE-12-2017-0009.

[7] C. Gan and W. Wang, "The influence of perceived value on purchase intention in social commerce context," Internet Res., vol. 27, no. 4, pp. 772-785, 2017, doi: https://doi.org/10.1108/IntR-06-2016-0164.

[8] N. Slack, G. Singh, and S. Sharma, "Impact of perceived value on the satisfaction of supermarket customers: developing country perspective," Int. J. Retail Distrib. Manag., vol. 48, no. 11, pp. 12351254, 2020, doi: https://doi.org/10.1108/IJRDM-03-2019-0099.

[9] M. D. Oosthuizen and J. Spowart, "The Relationship Between Perceived Price and Consumers' Purchase Intentions of Private Label Wine Brands," African J. Hosp. Tour. Leis., vol. 4, no. 2, pp. 1-17, 2015.

[10] L. A. Widyarini and S. Gunawan, "Predicting Consumer Purchase Intention on Fashion Products in Online Retailer: Integration of Self Determination Theory and Theory of Planned Behavior," Int. J. Emerg. Res. Manag. Technol., vol. 6, no. 9, p. 7, 2018, doi: 10.23956/ijermt.v6i9.78.

[11] K. I. Rohmatun and C. K. Dewi, "Pengaruh Pengetahuan dan Religiusitas Terhadap Niat Beli Pada Kosmetik Halal Melalui Sikap,' J. Ecodemica, vol. 1, no. 1, pp. 27-35., 2017.

[12] A. R. Firmansyah, "Pengaruh Pengetahuan Produk Dan Persepsi Kualitas Terhadap Niat Beli Mobil Datsun Go Panca," BISMA, vol. 9, no. 2, pp. 26-32, 2016.

[13] F. Ayuningsih, "The Influence of Product Knowledge, Brand Image, and Brand Love on Purchase Decision through Word of Mouth,' Manag. Anal. J., vol. 9, no. 4, p. 1, 2020, doi: 10.15294/maj.v9i4.40796.

[14] A. Y. A. Fianto, "The antecedents of purchase decision for hijab fashion products," Manag. Account. Res. J., vol. 12, no. 1, pp. 154 $165,2020$.

[15] N. W. W. Premayani and N. M. W. Kusumadewi, "Peran Corporate Image Dalam Memediasi Pengaruh Corporate Social Responsibility Terhadap Purchase Intention Air Minum Dalam Kemasan Merek Ades di Kota Denpasar," E-Jurnal Manaj. Unud, vol. 4, no. 6, pp. 1574-1590., 2015.

[16] C.-P. Li, "Effects of Brand Image, Perceived Price, Perceived Quality, and Perceived Value on the Purchase Intention towards Sports and Tourism Products of the 2016 Taichung International Travel Fair," $J$. Int. Manag. Stud., vol. 12, no. 2, pp. 97-107, 2017.

[17] A. A. I. C. Wiryantari and T. G. R. Sukawati, "Peran Persepsi Nilai Dalam Memediasi Pengaruh Kredibilitas Celebrity Endorser Pada Niat Beli Produk Kosmetik Wardah,” E-Jurnal Manaj. Unud, vol. 5, no. 22, pp. 7100-7127, 2016

[18] L. A. Kusuma and N. M. Purnami, "Pengaruh Persepsi Harga, Kepercayaan, Dan Orientasi Belanja Terhadap Niat Beli Secara Online (Studi Pada Produk Fashion Online Di Kota Denpasar)," E-
Jurnal Manaj. Unud, vol. 4, no. 8, pp. 2380-2406, 2015.

[19] L. G. Schiffman and L. L. Kanuk, Consumer Behavior, 11th ed. Global, 2015.

[20] A. R. Erida, "The Effect Of Brand Image, Product Knowledge and Product Quality On Purchase Intention Of Notebook With Discount Price As Moderating Variable," J. Bus. Stud. Manag. Rev., vol. 1, no. 11, pp. 26-32, 2017. 